Case Report

\title{
A Case of Old Calcifying Epithelioma Processed Symptomless over 40 Years
}

\author{
Shinji Yamaguchi, Madoka Inui, Takashi Takeoka, Kenya Okumura, and Toshiro Tagawa \\ Department of Oral and Maxillofacial Surgery, Department of Clinical Sciences, Medical Life Sciences, Mie University, \\ Graduate School of Medicine, 2-174 Edobashi, Tsu, Mie 514-8507, Japan \\ Correspondence should be addressed to Shinji Yamaguchi; sy1016-1984@clin.medic.mie-u.ac.jp
}

Received 27 May 2013; Accepted 19 June 2013

Academic Editors: S. R. Watt-Smith, E. F. Wright, and K. H. Zawawi

Copyright (C) 2013 Shinji Yamaguchi et al. This is an open access article distributed under the Creative Commons Attribution License, which permits unrestricted use, distribution, and reproduction in any medium, provided the original work is properly cited.

\begin{abstract}
Calcifying epithelioma, a benign tumor derived from the hair apparatus and consisted of hair matrix cells, is relatively prevalent in females. We report a case of right preauricular calcifying epithelioma that was incidentally detected at the examination of multiple facial fractures and became an old lesion without symptoms for 40 years. The patient who was a 42 -year-old male visited our department for the first time in October 2011 with a chief complaint of multiple facial fractures. Radiographic imaging demonstrated fracture lines at the anterior and posterior walls of the left maxillary sinus and zygomatic arch and revealed a mass at a right preauricular area. The extraction was performed under general anaesthesia. No recurrence has been observed 15 months after surgery. We also reviewed the literature of calcifying epithelioma.
\end{abstract}

\section{Introduction}

Calcifying epithelioma, a benign tumor derived from the hair apparatus and consisted of hair matrix cells, is relatively prevalent in females. It often develops on the face, neck, and upper limbs in the youth and is palpable as a hard nodule under the skin. Pathologically, it is mostly consisted of eosinophils and shadow cells, and the proportion of shadow cells increases over time, which leads to calcification and osteogenesis [1].

Although there are a number of reports on this tumor from the dermatology, reporting from the oral and maxillofacial region is relatively rare. We here report a case of calcifying epithelioma that was incidentally detected at the examination of multiple facial fractures and became an old lesion without symptoms for 40 years.

\section{Case}

A 42-year-old male visited our department for the first time in October 2011 with a chief complaint of multiple facial fractures. He had no past history or family history. As for the present history, he fell down from a bicycle and was hit severely in his left face in October 2011. He visited a nearby general hospital and was diagnosed with facial fractures. Then, he was referred to our department.

Radiographic imaging demonstrated fracture lines at the anterior and posterior walls of the left maxillary sinus and zygomatic arch and revealed a mass at a right preauricular area, well delineated radiopaque (Figure 1).

History taking revealed that his mother had noticed the mass when he was three years old, but there was no symptom. Since he hoped extraction, the right preauricular mass was resected at the same time with reduction and fixation of multiple facial fractures under general anesthesia.

General physical examination revealed average body constitution with excellent nutritious status and no abnormality. Extraoral findings revealed a depression at the cheek on the left, anesthesia, and palpebral subconjunctival hemorrhage on the left, but there was no motility disorder of the left eyeball, double vision, or occlusal deviation. A bone-like hard mass about $10 \mathrm{~mm}$ in size was palpable subcutaneously at the right preauricular area. The mass was well delineated without adhesion to the adjacent tissue. The surface of the skin 


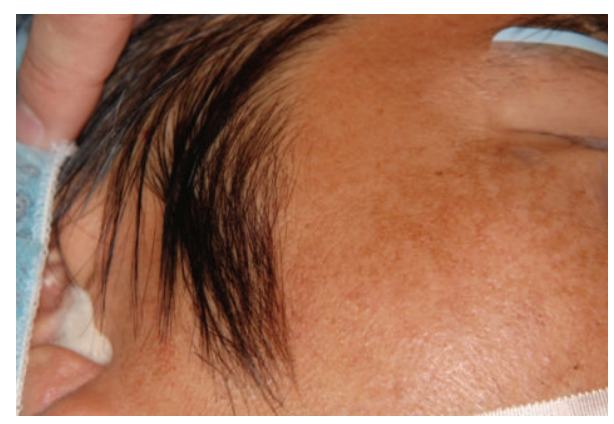

FIGURE 1: Revealed mass at the right preauricular area.

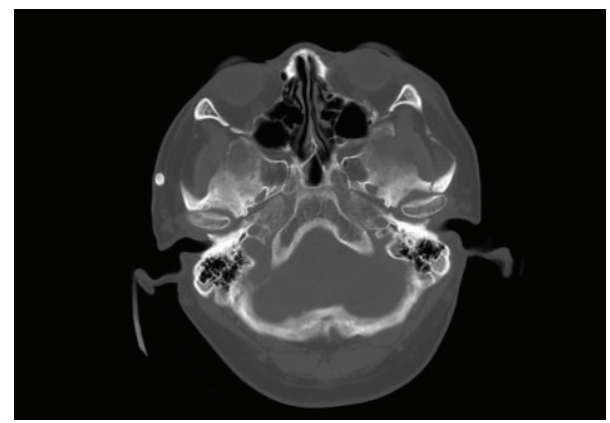

FIgURE 2: A bone-like hard mass about $10 \mathrm{~mm}$ in size was palpable subcutaneously at the right preauricular area.

showed a healthy color, and the mass developed no symptom or growing tendency from the childhood (Figure 2).

In the oral cavity, there was no abnormal finding, and the excretion and nature of saliva were normal.

Tentative diagnosis of maxillary fracture and preauricular benign tumor was made, and the right preauricular mass was resected at the same time with open reduction and fixation of multiple left facial fractures. A horizontal skin incision was made about $1 \mathrm{~cm}$ from the top of the mass, and the mass was dissected from the adjacent tissue. The mass had no adhesion with the adjacent tissue, and it was resected en bloc.

The resected specimen was hard and yellowish white 10 $\times 9 \mathrm{~mm}$ in size, and the cross section showed a coarse and bone-like surface (Figure 3). Dental X-rays showed an image of patchy calcification in the mass (Figure 4).

\section{Pathological Findings}

Aggregation of shadow cells and surrounded bone tissue were observed. At the stroma, multinuclear giant cells are sparsely observed, and there was no infiltration of eosinophils. Old calcifying epithelioma with ossification was diagnosed (Figures 5(a) and 5(b)).

\section{Discussion}

Calcifying epithelioma, mostly consisted of eosinophils, shadow cells, and transitional cells, exhibits a variety of images of calcareous deposits, bone formation, foreign-body giant cells, and melanin deposits. It is known that the

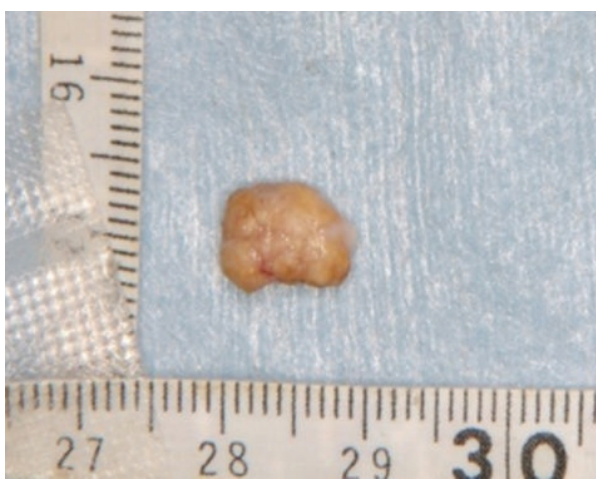

FIgURE 3: The excised specimen was hard and yellowish white $10 \times$ $9 \mathrm{~mm}$ in size, and the cross section showed a coarse and bone-like surface.

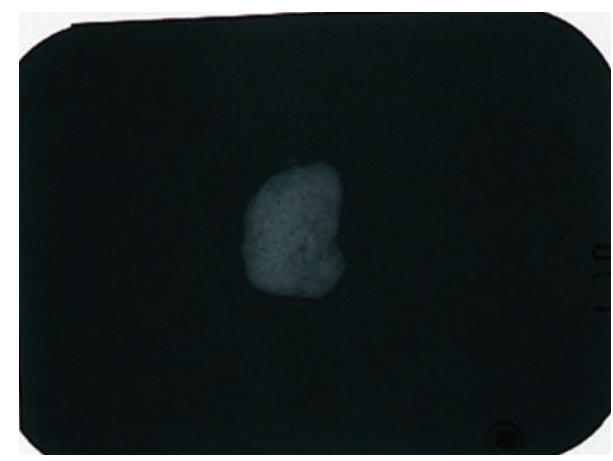

FIgURE 4: Dental X-rays showed an image of patchy calcification in the mass.

component ratio of eosinophils to shadow cells in this tumor changes as disease stages advance and tumor parenchyma is rich in eosinophils at the early stage, whereas shadow cells are predominant in the old tumor with almost no eosinophil infiltration $[2,3]$. Moreover, the tumor is characterized by calcification, but calcification is not always accompanied. Calcification is mostly observed in shadow cells, and it is considered dystrophic calcification associated with degeneration and necrosis of shadow cells [1].

We experienced a case of calcifying epithelioma that was incidentally detected as a circle-like radiopaque finding by $\mathrm{CT}$ in a patient with multiple facial fractures and diagnosed by history taking as an old lesion without symptoms for about 40 years. The prognosis of the tumor is generally excellent, but recurrent cases have been reported [1,4], and malignant change after repeated recurrences has also been reported [5, 6]. In our case, despite a short postoperative follow-up period of about fifteen months, no recurrence has been observed.

Moehlenbeck [7] mentioned that this tumor occurred at younger than 10 years old in more than $40 \%$ of 900 cases examined at the dermatology department, and patients developed symptoms in their 30 s or at younger age in more than $60 \%$ with an average period of 4.4 years from appearance to extraction. Cases without symptoms for a long time, such as this case for 40 years, are rare. 


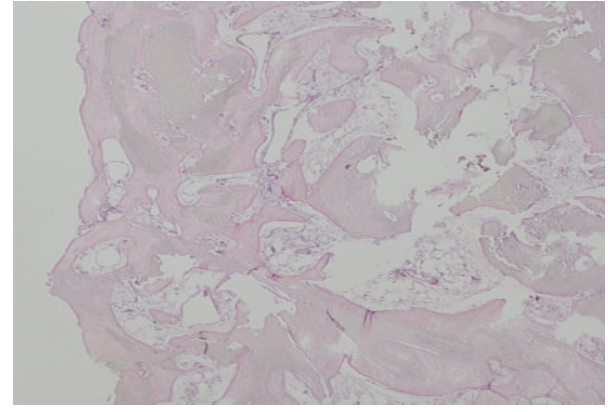

(a)

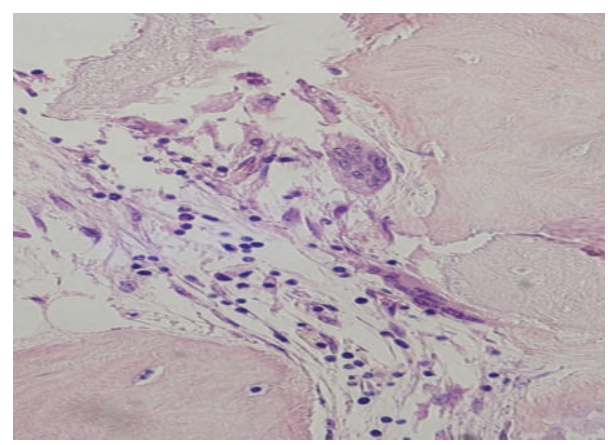

(b)

Figure 5: Pathological findings $1(\mathrm{H}-\mathrm{E}, \times 40$ and 400): aggregation of shadow cells and surrounded bone tissue were observed. At the stroma, multinuclear giant cells are sparsely observed, and there was no infiltration of eosinophils. Old calcifying epithelioma with ossification was diagnosed.

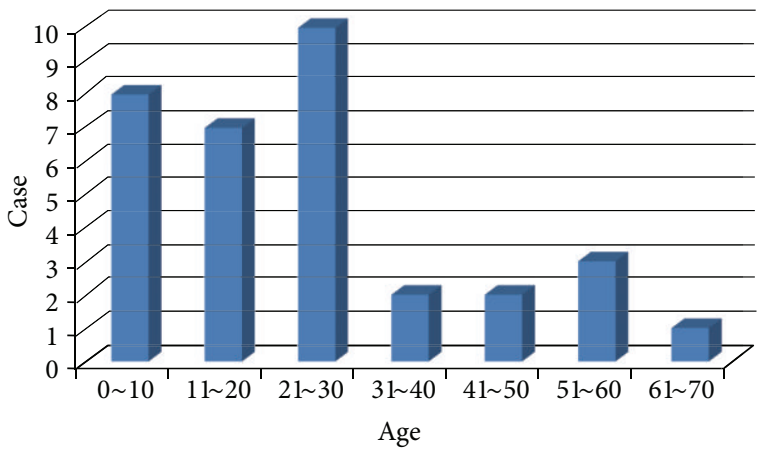

FIGURE 6

In Japan, 33 cases of calcifying epithelioma in the oral and maxillofacial region were reported between 1978 and 2012 including our case $[2-4,8-24]$. The age distributed from 4 to 68 years old, and the average age was 23.8 years. The most frequent site of occurrence is periauricular in 18 cases, followed by the cheek in 8 , neck in 5 , and angle of the mandible in 2. Disease duration ranged from 1 month to 40 years with the average of 5.8 years. The tumor diameter ranged from $4 \mathrm{~mm}$ to $50 \mathrm{~mm}$ with the average of $22.1 \mathrm{~mm}$ (Table 1, Figures 6 and 7).

Pathologically, there were 9 cases with only shadow cells without eosinophils, 13 with bone formation, and 17

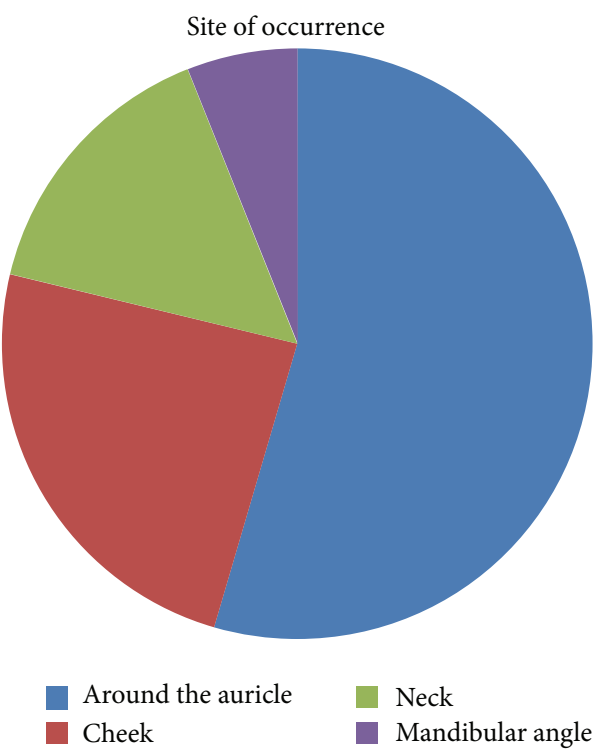

Figure 7

with giant cells, while there were only 3 cases with only shadow cells accompanied by bone formation and giant cells, including our case.

Then, we focused on the occurrence of the tumor and the period of its presence in vivo. However, since it is impossible to clearly determine the period of its presence in vivo, it was examined how the duration from the time when a mass was noticed to extraction (disease duration) was associated with the proportion of eosinophils to shadow cells and the presence or absence of bone formation and giant cells. The average disease duration was 13.9 years in cases with only shadow cells, while it was 2.7 years in cases with both eosinophils and shadow cells, and it was significantly longer in the former cases $(P<0.01)$. With regard to osteogenesis, the average disease duration was 11.5 years in cases with bone formation, while it was 0.8 years in cases without it, and it was significantly longer in the former cases $(P<0.001)$. The average disease duration was 4.0 years in cases with giant cells, while it was 7.1 years without them, and there was no significant difference between the former and latter cases.

Taken together, the present case with only shadow cells and bone formation was considered an old one. Bone formation is thought to appear subsequent to calcification [1], and Anneroth and Sigurdson mentioned that giant cells were osteoclast-type cells without phagocytic capacity in giant cell epulis and the stroma was rich in fibroblasts and osteoblasts, which differentiated into bone and osteoid tissue, eventually forming bone [25].

Since dye affinity changed from eosinophilic to basophilic properties in the parenchyma just beneath the osteoclast-like multinuclear giant cells around the edge of the calcified tumor parenchyma, Miyahara et al. reported that the edge of the calcified layer was decalcified and subsequently osteoblasts were induced to form bone, and a mechanism similar to general bone remodeling was present even in ectopic osteogenesis [24]. 


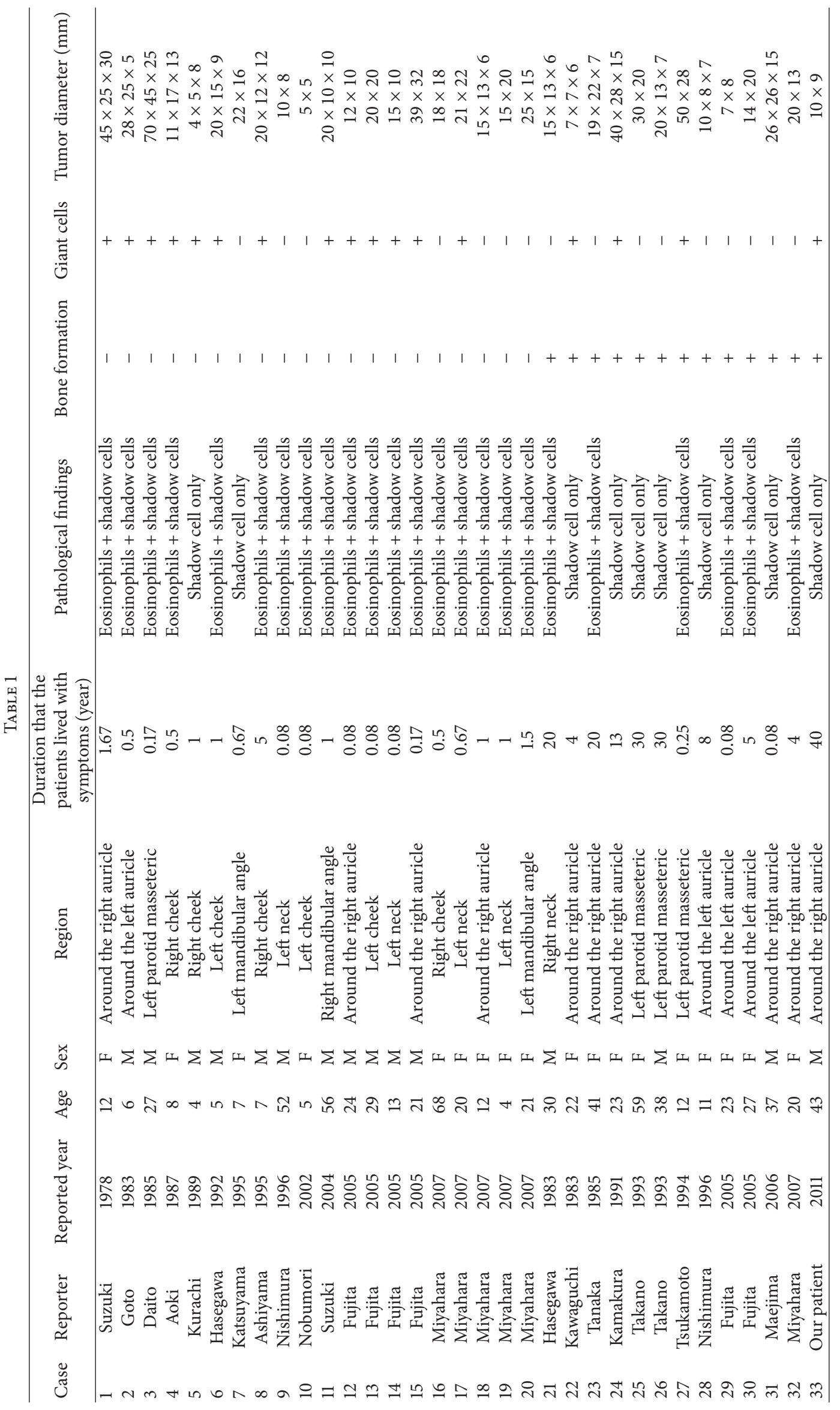


In the present case, disease duration and formation of giant cells and bone were discussed with references, but no giant cell was observed in any case at the early stage. Therefore, it was speculated that the component proportion of eosinophils to shadow cells changed as disease stages advanced, and as shadow cells became predominant, giant cells appeared in the stroma, which promoted osteogenesis subsequently to calcification.

In conclusions, we reported a case of calcifying epithelioma that became an old lesion without symptoms for 40 years. In 33 cases reported in our country from the oral and maxillofacial region, including our case, pathological characteristics and disease duration were compared by clinical statistics.

\section{References}

[1] R. Forbis and E. B. Helwig, "Pilomatrixoma (calcifying epithelioma)," Archives of Dermatology, vol. 83, no. 4, pp. 606-618, 1961.

[2] K. Fujita, H. Harada, S. Hasegawa, H. Imai, Y. Kabasawa, K. Morita et al., "Clinicopathological study of calcifying epithelioma in the head and neck region," Journal of Oral and Maxillofacial Surgery, vol. 51, pp. 285-290, 2006 (Japanese).

[3] N. Nishimura, S. Iida, M. Takeda, T. Sakai, H. Yamaoka, and T. Kimura, "Two cases of calcifying epithelioma arising at the periauricular region," Journal of Oral and Maxillofacial Surgery, vol. 42, pp. 693-695, 1996 (Japanese).

[4] K. Suzuki, K. Fujita, T. Nakashima, T. Tomikawa, K. Miyake, M. Masuda et al., "Case of calcifying epithelioma in the right subauricular region," Journal of Oral and Maxillofacial Surgery, vol. 24, pp. 619-622, 1978 (Japanese).

[5] S. Lopansri and M. C. Mihm, "Pilomatrix carcinoma or calcifying epitheliocarcinoma of Malherbe. A case report and review of literature," Cancer, vol. 45, no. 9, pp. 2368-2373, 1980.

[6] J. D. Van Der Walt and B. Rohlova, "Carcinomatous transformation in a pilomatrixoma," American Journal of Dermatopathology, vol. 6, no. 1, pp. 63-69, 1984.

[7] F. W. Moehlenbeck, "Pilomatrixoma (calcifying epithelioma) a statistical study," Archives of Dermatology, vol. 108, no. 4, pp. 532-534, 1973.

[8] M. Maejima, Y. Sato, and K. Masumoto, "Calcifying epithelioma arising in the subauricular region," Journal of Oral and Maxillofacial Surgery, vol. 19, no. 2, pp. 339-344, 2006 (Japanese).

[9] S. Suzuki, T. Takemoto, Y. Ishida, H. Inamoto, and Y. Kameyama, "A case of calcifying epithelioma due to traumatic injury in the submandibular region," Journal of Japanese Society for Oral Mucous Membrane, vol. 10, no. 2, pp. 36-40, 2004 (Japanese).

[10] M. Takano, K. Tominaga, H. Furusawa, Y. Kuga, A. Mizuno, Y. Shibata et al., "Two cases of calcifying epithelioma arising in the parotid-masseteric region," Journal of Oral and Maxillofacial Surgery, vol. 39, no. 12, pp. 88-90, 1993 (Japanese).

[11] S. Kamakura, R. Sato, Y. Fujita, K. Motegi, and K. Ohya, "Pilomatrixoma (calcifying epithelioma of Malhebe) in the right subauricular region," Journal of Oral and Maxillofacial Surgery, vol. 37, no. 5, pp. 1002-1006, 1991 (Japanese).

[12] M. Ashihara, K. Komatsu, R. Fukui, K. Nakayama, T. Akitaya, A. Narita et al., "Calcifying epithelioma in the right cheek region: report of a case," Pediatric Oral and Maxillofacial Surgery, vol. 5, pp. 105-108, 1995 (Japanese).
[13] T. Kazuyama, Y. Hayatsu, T. Tsuji, J. Hirayama, and F. Shinozaki, "A case of calcifying epithelioma in the cheek region," Pediatric Oral and Maxillofacial Surgery, vol. 5, pp. 80-83, 1995 (Japanese).

[14] T. Nobumori, Y. Itoh, K. Ohta, H. Tohmori, S. Inoue, M. Sugiyama et al., "A case of calcifying epithelioma of the cheek in a childhood," Pediatric Oral and Maxillofacial Surgery, vol. 12, pp. 29-32, 2002 (Japanese).

[15] G. Tsukamoto, A. Sasaki, and T. A. Matsumura, "Case of rapidly growing calcifying epithelioma in the parotidomasseteric region," Journal of Oral and Maxillofacial Surgery, vol. 40, no. 1, pp. 215-217, 1994.

[16] Y. Kurachi, H. Sakamaki, M. Manabe, R. Kamijo, M. Nagumo, Y. Kohno et al., "A case of calcifying epithelioma in the cheek region," Journal of Oral and Maxillofacial Surgery, vol. 35, pp. 176-182, 1989 (Japanese).

[17] H. Hasegawa and Y. Matsuzaki, "Calcifying epithelioma in the left cheek region: report of a case," Journal of Oral and Maxillofacial Surgery, vol. 38, no. 4, pp. 699-700, 1992.

[18] S. Aoki, M. Osada, R. Kawabe, S. Ono, and K. Fujita, "Calcifying epithelioma in the right cheek region: report og a case," Journal of Oral and Maxillofacial Surgery, vol. 33, no. 3, pp. 609-614, 1987 (Japanese).

[19] M. Tanaka, Y. Sangu, T. Takeuchi, H. Ogiuchi, and I. Kawanishi, "Calcifying epithelioma in the right subauricular region: report of a case," Journal of Oral and Maxillofacial Surgery, vol. 31, no. 6, pp. 1483-1486, 1985 (Japanese).

[20] T. Kawaguchi, K. Kodama, and A. Taen, "Calcifying epithelioma in the left subauricular region: report of a case," Journal of Oral and Maxillofacial Surgery, vol. 29, no. 9, pp. 1661-1666, 1983 (Japanese).

[21] Y. Daito, Y. Takayama, H. Yamanoi, M. Miyake, T. Misaki, I. Kudo et al., "A case of calcifying epithelioma which was doubted a parotid gland origin tumor," Journal of Oral and Maxillofacial Surgery, vol. 31, no. 5, pp. 1099-1103, 1985 (Japanese).

[22] H. Hasegawa, T. Kawai, M. Shirakawa, A. Ikai, and H. Tanabe, "Calcifying epithelioma in the lateral neck," Journal of Oral and Maxillofacial Surgery, vol. 29, pp. 1579-1583, 1983 (Japanese).

[23] K. Goto, K. Mogi, A. Takeuchi, Y. Yokoyama, M. Yokobori, T. Shiba et al., "A case of calcifying epithelioma in the left preauricular region," Journal of Oral and Maxillofacial Surgery, vol. 29, no. 5, pp. 969-974, 1983 (Japanese).

[24] M. Miyahara, J. Tanuma, K. Kawashima, E. Nozoe, I. Semba, and K. A. Sugihara, "Case of calcifying epithelioma with marked calcification and ossification," Journal of Oral and Maxillofacial Surgery, vol. 53, no. 8, pp. 499-503, 2007 (Japanese).

[25] G. Anneroth and A. Sigurdson, "Hyperplastic lesions of the gingiva and alveolar mucosa. A study of 175 cases," Acta Odontologica Scandinavica, vol. 41, no. 2, pp. 75-86, 1983. 


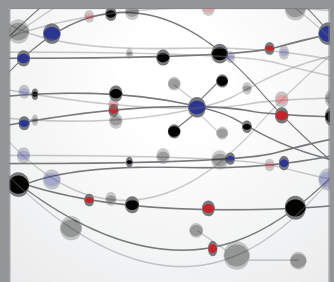

The Scientific World Journal
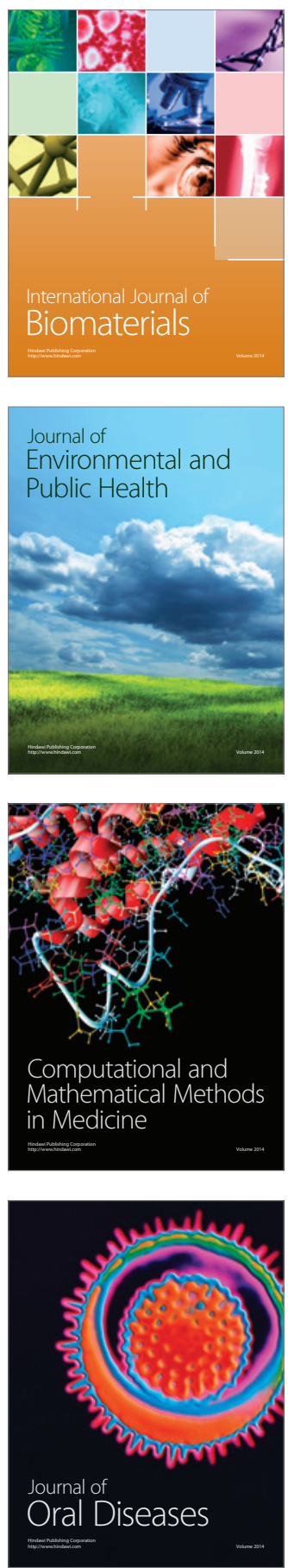
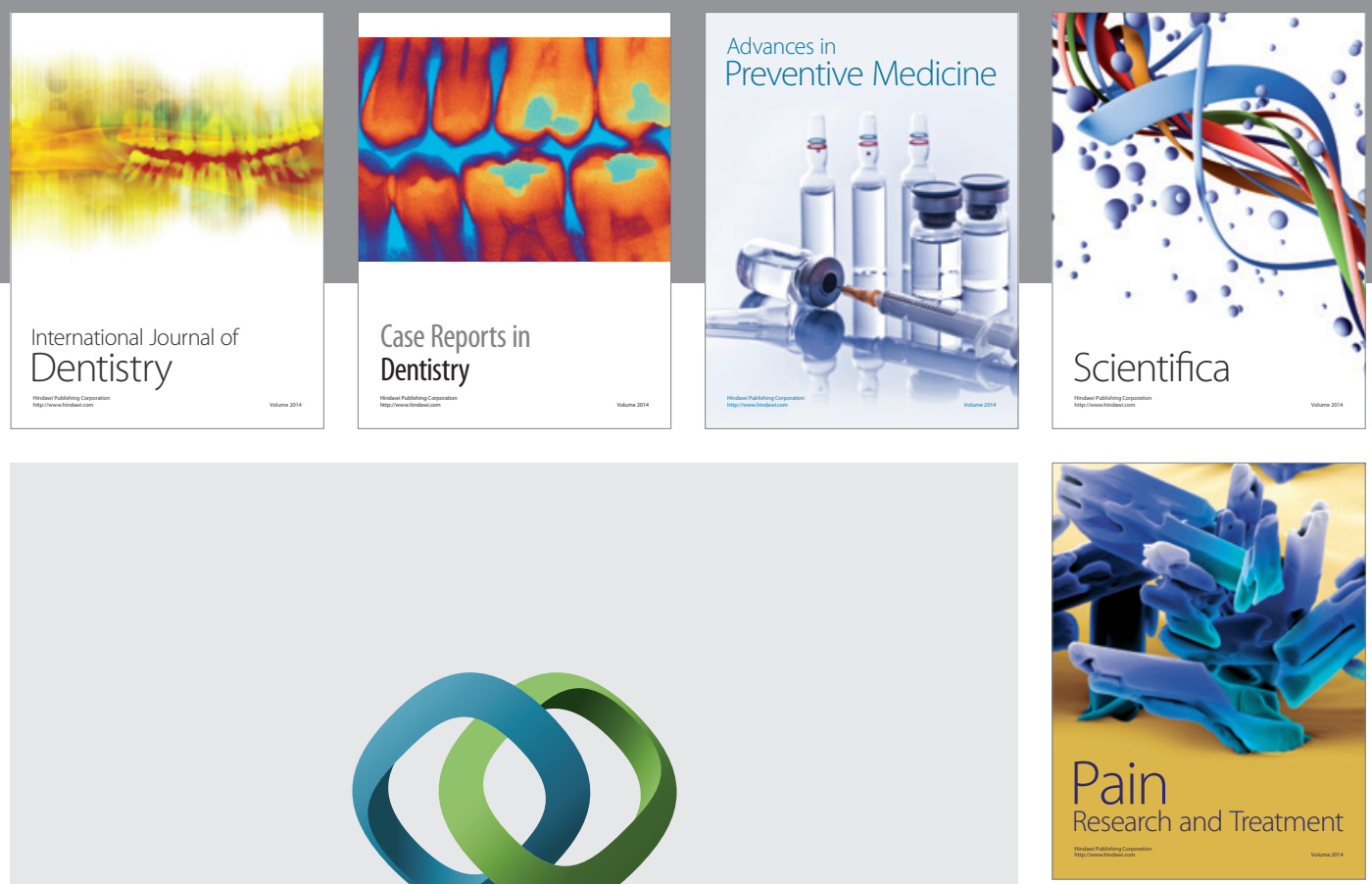

\section{Hindawi}

Submit your manuscripts at

http://www.hindawi.com
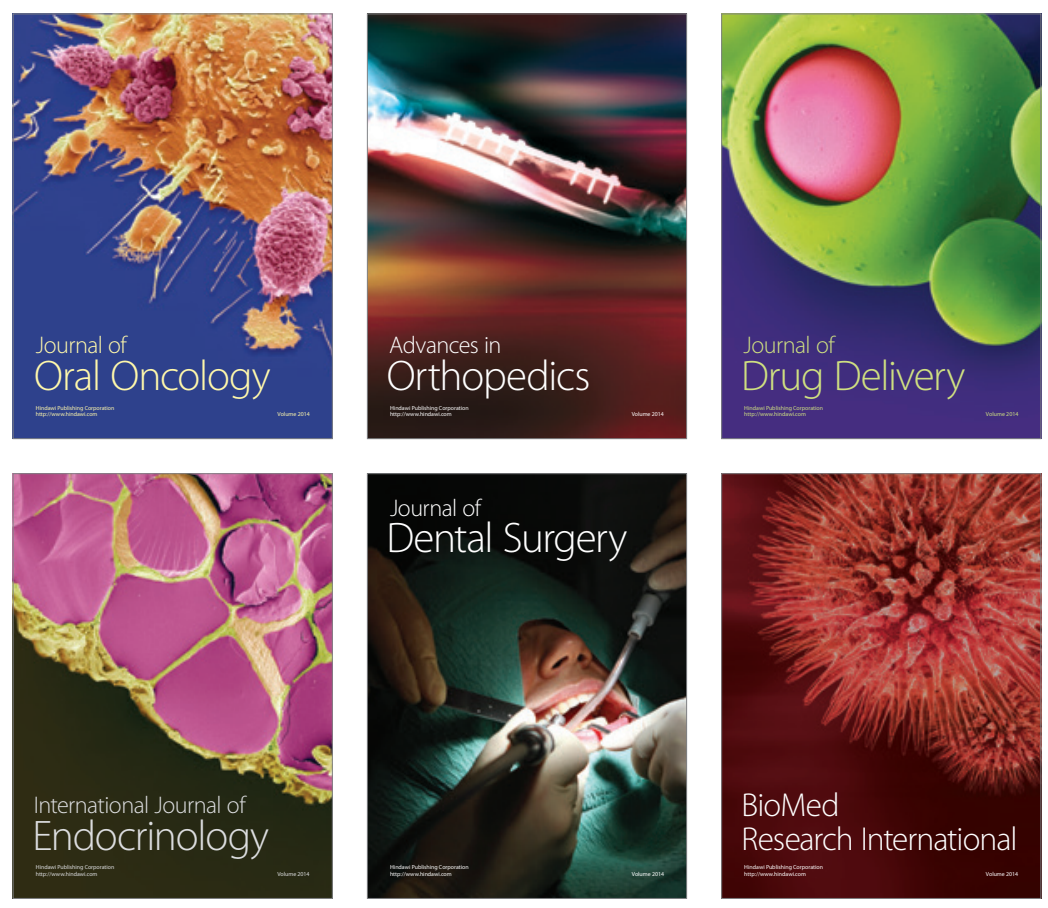

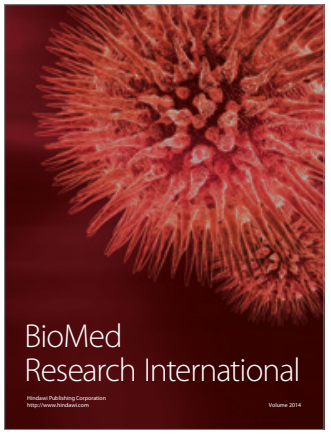

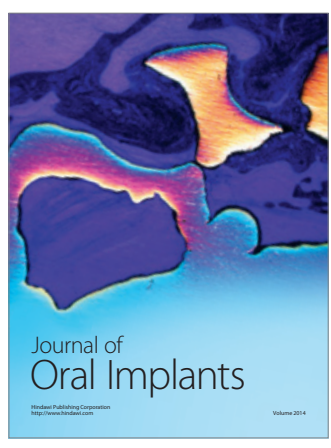
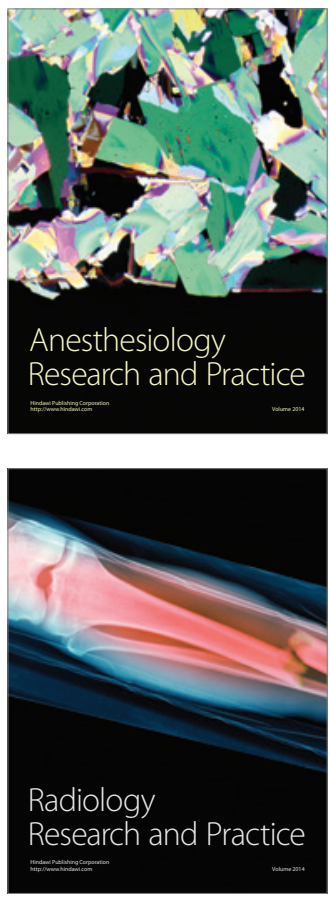